\title{
Liquidity Trap, the Case of Albania
}

\author{
Prof.As.Dr. Alqi Naqellari
}

Mediterranean University of Albania alqinaqellari@umsh.edu.al

\section{PHD.Ilir Hebovia}

Mediterranean University of Albania ilir@umsh.edu.al

\section{Prof.As.Dr. Nexhmi Dumani}

Mediterranean University of Albania nexhod@umsh.edu.al

\section{Doi:10.5901/ajis.2016.v5n3p95}

\begin{abstract}
The liquidity trap is a rare economic phenomenon. It is associated with the phenomenon of deflation and other economic phenomena with negative consequences for the economy. It is caused by switching positions to extreme curves of aggregate demand and supply, the demand for loans, deposits, etc. This means that curbs of these aggregates pass almost completely horizontal or almost completely vertical. In the case of the Albanian economy these aggregates are insensitive by changes of basic interest rate and repo rate. The data of the last 19 months shows this situation. This makes the monetary policy of the Bank of Albania lose trasmision. Lose of this effect consequently leads to not influence monetary policy to the economic growth. In these conditions economic growth is affected expansionary by fiscal policies applied by the government. Since the inflation rate is low, and in downward trend, we propose money emission to increase the amount of money in circulation. With this move will increase aggregate demand by stimulating the growth of aggregate supply. In this paper have used analysis, comparison, synthesis, description and statistical-econometric methods.
\end{abstract}

Keywords: deflation, inflation, monetary policy, fiscal policy, basic interest rate, monetary suply, economic growth, unemployment rate, exchange rate, export-import, etc.

\section{Introduction}

Liquidity trap since it is connected with the monetary aggregates and express their positions is associated with monetary policies and their effects, transmission. In this way, monetary policy actions and their effects on the economy reflected in IS-LM curves which are equilibrium curve expressing the relationship between income and the interest rate when the goods markets and monetary markets are in equilibrium. Albanian economy for 4 months in 2015 had deflation, while in other months had an inflation rate around zero. In recent months decreased interest on loans and deposits. This happened after the last cuts the repo rate by The Bank of Albania. Reduction of deposits is normal and expected because of the decrease of interest rates. While the decline of the stock of loans to businesses in Albanian Currency. This is a common phenomenon with no negative impacts on the economy. With the reduction of interest rates, the stock of credit would normally grow, in fact it has declined.

Which are some of the factors of this decrease?

- High level of problematics and lost loans.

- Mistrust of banks to businesses.

- Numerous documents and obstacles that bring business to the banks.

- High interest rate on loans in Albanian Currency.

- Problems on Executions collateral.

- Level of Loans in euro and dollar.

- Informal-Loans of different subjects, etc. 
The analysis of economic factors, it was concluded that the effects of monetary policy are very low in the economy, therefore the government should interfere with expansionary policies. Below you will see, using the data of the Bank of Albania monetary aggregates, the positions of the curves L, M2, I, IS and LM. In the analysis we will examine in turn these indicators and the connection between:

\section{Theorical Description of the Liquidity Trap}

Liquidity trap is a situation, described in Keynesian economics, in which injections of cash into the private banking system by a central bank fail to decrease interest rates and hence make monetary policy ineffective. A liquidity trap is caused when people hoard cash because they expect an adverse event such as deflation, insufficient aggregate demand, or war. Common characteristics of a liquidity trap are interest rates that are close to zero and fluctuations in the money supply that fail to translate into fluctuations in price levels The most important question in this situation can be: What attitude will keep workers and employers in a steady decline, which could complicate the situation continue to deteriorate?. Workers predicting bankruptcy of many companies unemployment could rise further, take precautions to keep their money in the hands of too little spending on consumer goods. On the other hand, entrepreneurs seeing demand for consumer goods does not increase but remains down, also keep the money in their hands and they prefer not to invest.

According to Keynsianists using IS-LM model to analyze the liquidity trap, we see how a monetary expansion does not affect interest rates (i) or at the level of GDP (Y). Just fiscal expansion leads to a higher level of GDP (Y) without changes in interest rates.

Theoretical liquidity trap is a situation where the demand for money is completely flexible in relation to the interest rate, that is to say, increases consecutive in the money supply fail to further reduce rates and, therefore, encourage investment and consumption. This happens when interest rates are so low that only agents can expect it to grow in the future.

Low rates make economic entities to hold liquid assets, rather than to invest. On the other hand, this situation requires care to invest in bonds, because their price is high because of falling interest rates and expected rise. As result, injections of liquidity set aside instead be used for productive investments since they are completely ineffective.

In terms of Hicksiane analysis (IS-LM) LM courve is horizontal, so that only the expansionary fiscal policy (which operates on IS) can increase production and employment, and does not cause pressure to increase interest rates, consequently there is the effect of the removal of private investment (crowding-out). In such circumstances, fiscal policy is the time to resume investments in infrastructure and to protect the purchasing power of the poor.

Cruman explains the theory of Keynes' liquidity trap:

"Before Keynes, economists considered the money supply a primary tool of economic management. But he argued that under depression when interest rates are very low, changes in the money supply have little impact on the economy. The logic was as follows: when interest rates are $4 \%$ or $5 \%$, no one wants their money to remain unemployed, but in a situation like in 1935, when the interest rate of treasury bills in three months fellt to $0,14 \%$, there is little incentive to take the risk of putting money in the bank.

If the interest rate is very low, it is likely that banks suffer money extension because people keep them at home. Consequently, Keynes argued that monetary policy through the change of money supply to manage the economy, will be inefficient. In this way he and his followers believed that it was necessary to increase public spending to bring the economy into balance. In this paper we will prove this trend, but given the inelastic aggregate and not by LM completely horizontal.

\section{Relationship between Monetary Aggregates and BIR (Basic Interes Rate = Weekly Repurchase Agreement)}

Analysis of the links between monetary aggregates and interest rate.

Table 1: Monetary aggregates by July 2014 to January 2016.

in million lek

\begin{tabular}{|c|c|c|c|c|c|c|c|c|}
\hline & $\mathbf{M}_{3}$ & $\mathbf{M}_{\mathbf{2}}$ & $\mathbf{M}_{\mathbf{1}}$ & $\begin{array}{c}\text { Currency outside } \\
\text { depository corporations }\end{array}$ & $\begin{array}{c}\text { Time deposits in } \\
\text { national currency }\end{array}$ & $\begin{array}{c}\text { Total Time } \\
\text { deposits }\end{array}$ & $\begin{array}{c}\text { Total } \\
\text { deposits }\end{array}$ & $\begin{array}{c}\text { BIR \% Weekly repurchase } \\
\text { agreement }\end{array}$ \\
\hline & $\mathbf{X}_{\mathbf{1}}$ & $\mathbf{X}_{2}$ & $\mathbf{X}_{\mathbf{3}}$ & $\mathbf{X}_{\mathbf{4}}$ & $\mathbf{X}_{5}$ & $\mathbf{X}_{6}$ & $\mathbf{X}_{\mathbf{7}}$ & $\mathbf{Y}$ \\
\hline Jul & $1,159,811.30$ & $697,654.00$ & $314,570.80$ & $202,024.40$ & $383,083.20$ & $714,211.00$ & $845,240.50$ & 2.50 \\
\hline Aug & $1,168,146.30$ & $695,333.10$ & $319,092.30$ & $205,810.70$ & $376,240.80$ & $708,709.30$ & $849,054.00$ & 2.50 \\
\hline Sep & $1,165,904.50$ & $694,944.60$ & $318,974.60$ & $206,139.60$ & $375,969.90$ & $708,218.90$ & $846,929.80$ & 2.50 \\
\hline
\end{tabular}




\begin{tabular}{|l|l|l|l|l|l|l|l|l|} 
Oct & $1,162,722.70$ & $695,395.90$ & $318,928.60$ & $204,022.70$ & $376,467.30$ & $706,424.20$ & $843,794.10$ & 2.50 \\
\hline Nov & $1,165,843.80$ & $700,418.10$ & $325,079.30$ & $206,715.10$ & $375,338.70$ & $700,784.20$ & $840,764.50$ & 2.50 \\
\hline Dic & $1,195,086.30$ & $722,356.70$ & $353,321.70$ & $217,665.60$ & $369,035.00$ & $693,907.70$ & $841,764.60$ & 2.25 \\
\hline Jan & $1,188,009.10$ & $714,347.90$ & $346,305.10$ & $215,043.40$ & $368,042.80$ & $692,056.70$ & $841,704.00$ & 2.00 \\
\hline Feb & $1,192,174.70$ & $717,983.00$ & $349,688.40$ & $217,290.40$ & $368,294.70$ & $690,291.70$ & $842,486.40$ & 2.00 \\
\hline Mar & $1,190,772.30$ & $715,949.60$ & $347,957.90$ & $216,414.70$ & $367,991.80$ & $689,356.10$ & $842,814.50$ & 2.00 \\
\hline Apr & $1,193,011.40$ & $717,583.80$ & $350,671.90$ & $217,266.10$ & $366,912.00$ & $684,707.40$ & $842,339.60$ & 2.00 \\
\hline May & $1,198,833.10$ & $724,470.30$ & $358,825.40$ & $222,645.40$ & $365,644.90$ & $683,836.30$ & $840,007.70$ & 2.00 \\
\hline Jun & $1,197,817.60$ & $725,252.90$ & $363,298.80$ & $226,484.20$ & $361,954.10$ & $675,156.20$ & $834,518.80$ & 2.00 \\
\hline Jul & $1,198,904.80$ & $725,413.40$ & $368,185.40$ & $230,392.20$ & $357,228.10$ & $666,458.30$ & $830,719.50$ & 2.00 \\
\hline Aug & $1,203,371.80$ & $721,747.90$ & $369,339.70$ & $228,606.60$ & $352,408.20$ & $659,955.00$ & $834,032.00$ & 2.00 \\
\hline Sep & $1,198,897.80$ & $716,995.60$ & $368,225.20$ & $225,779.50$ & $348,770.40$ & $654,940.00$ & $830,672.60$ & 2.00 \\
\hline Oct & $1,197,015.10$ & $713,395.00$ & $367,286.30$ & $225,028.50$ & $346,108.70$ & $650,440.30$ & $829,728.80$ & 2.00 \\
\hline Nov $1,197,935.50$ & $710,899.40$ & $367,178.70$ & $223,793.30$ & $343,720.70$ & $646,855.50$ & $830,756.80$ & 1.75 \\
\hline Dic & $1,217,870.10$ & $723,744.60$ & $384,108.20$ & $230,602.70$ & $339,636.50$ & $639,843.60$ & $833,762.00$ & 1.75 \\
\hline Jan & $1,211,534.40$ & $712,281.60$ & $374,877.80$ & $225,423.10$ & $337,403.60$ & $640,775.60$ & $836,656.60$ & 1.75 \\
\hline
\end{tabular}

Source: Bank of Albania, INSTAT. Sthatistical Raports of 2015, 2014.

Correlation of this aggregates:

\begin{tabular}{|c|c|c|c|c|c|c|c|c|}
\hline & $M_{3}$ & $M_{2}$ & $M_{1}$ & $\begin{array}{c}\text { Currency outside } \\
\text { depository corporations }\end{array}$ & $\begin{array}{l}\text { Time deposits in } \\
\text { national currency }\end{array}$ & $\begin{array}{c}\text { Total Time } \\
\text { deposits }\end{array}$ & $\begin{array}{c}\text { Total } \\
\text { deposits }\end{array}$ & BIR \% \\
\hline & $X_{1}$ & $X_{2}$ & $X_{3}$ & $X_{4}$ & $X_{5}$ & $X_{6}$ & $X_{7}$ & $Y$ \\
\hline$\overline{X_{1}}$ & 1 & & & & & & & \\
\hline$X_{2}$ & 0.864 & 1 & & & & & & \\
\hline$X_{3}$ & 0.981 & 0.844 & 1 & & & & & \\
\hline$X_{4}$ & 0.949 & 0.867 & 0.980 & 1 & & & & \\
\hline$X_{5}$ & -0.860 & -0.537 & -0.906 & -0.856 & 1 & & & \\
\hline$X_{6}$ & -0.872 & -0.588 & -0.927 & -0.888 & 0.994 & 1 & & \\
\hline$X_{7}$ & -0.715 & -0.605 & -0.837 & -0.855 & 0.838 & 0.881 & 1 & \\
\hline$Y$ & -0.933 & -0.766 & -0.925 & -0.876 & 0.850 & 0.864 & 0.703 & 1 \\
\hline
\end{tabular}

Data processing: By authors.

Analysis of the links between monetary aggregates is the same except for their connections with the average inflation rate that has changed.

$=\mathrm{BIR}$ has no direct relation with the indicator of total deposits with $\mathrm{k}=0.703$. This means that the repo rate cut has affected the reduction of total deposits, therefore, had a negative impact. Lowering the repo is accompanied by the commercial banks to reduce interest rates on deposits. Affected pleasurable $k=-802$ in the opposite in total deposits in foreign currency. This means that the decline rates has the opposite deposits with foreign currency deposits. So if repo are significantly reduced total foreign currency deposits increased significantly. This is because the rates on deposits in Albanian Lek were reduced more than those in foreign currency.

= BIR has no direct relation and same direction with Lek deposits, total term deposits and term deposits in foreign currency. The correlation coefficient with respect to deposits in Lek is greater than +0.85 , indicating that there is a strong bond, assessable. It is precisely the reduction of the repo rate that has slashed the deposit rate. This has made economic entities be indifferent to them and find other investment opportunities, such as Treasury Bonds or direct investments through informal street in construction firms.

$=$ BIR has strong and contrasting relation with money outside banks, aggregates $M_{1}, M_{2}$ and $M_{3}$. This connection is normal and expected given the report in relation to deposits in domestic and related currency. $M_{1}$ has a strong relation because it includes money outside banks plus demand in no term deposits, which have increased in comparison with term deposits.

$=X_{1}\left(M_{3}\right)$ has strong and same directions with $M_{2}, M_{1}$ and currency outside banks, and has strong relations with the opposite direction with term deposits in domestic currency. This means that other elements of the aggregate have given greater impacts on their reverse. This is also seen in foreign currency deposits which have strong links to the $M_{3}$ biased. 
Table No. 2. Connection between the average annual inflation $(Y)$ and monetary aggregates is as follows.

\begin{tabular}{|c|c|c|c|c|c|c|c|c|}
\hline & $\mathbf{M}_{\mathbf{3}}$ & $\mathbf{M}_{\mathbf{2}}$ & $\mathbf{M}_{\mathbf{1}}$ & $\begin{array}{c}\text { Currency outside } \\
\text { depository corporations }\end{array}$ & $\begin{array}{c}\text { Time deposits in } \\
\text { national currency }\end{array}$ & $\begin{array}{c}\text { Total Time } \\
\text { deposits }\end{array}$ & $\begin{array}{c}\text { Total } \\
\text { deposits }\end{array}$ & $\begin{array}{c}\text { The average inflation } \\
\text { rate(Annual) }\end{array}$ \\
\cline { 2 - 9 } & $\boldsymbol{X}_{\mathbf{1}}$ & $\boldsymbol{X}_{\mathbf{2}}$ & $\boldsymbol{X}_{\mathbf{3}}$ & $\boldsymbol{X}_{\mathbf{4}}$ & $\boldsymbol{X}_{\mathbf{5}}$ & $\boldsymbol{X}_{\mathbf{6}}$ & $\boldsymbol{X}_{\mathbf{7}}$ & $\boldsymbol{Y}$ \\
\hline The average inflation rate & 0.411 & -0.021 & 0.425 & 0.333 & -0.685 & -0.646 & -0.4 & 1 \\
\hline BIR & -0.933 & -0.766 & -0.925 & -0.876 & 0.850 & 0.864 & 0.703 & 1 \\
\hline
\end{tabular}

The correlation coefficient between the repo July 2014 and January 2016 and the annual average inflation rate for the same period is -0401 .

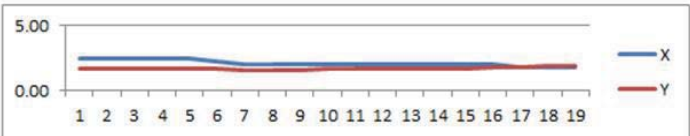

Chart No.1 Dynamics of average inflation rate and bir

In a normal economy, with full effect this connection, transmission should be very strong. In Albania there is strong because there is a very significant impact on the market, of two currencies, euro and dollar. Lek introduced in fair competition with them because its base rate is many times higher than the base rate of the euro and the dollar, which tend to zero.

Relevance in the opposite direction is reflected by the average connection rate of inflation in the monetary aggregates in the first table of aggregates above. First four agregats have weak links with the average annual rate of inflation. Has reverse relation with Term deposits in ALL and taken into consideration. This means that when increase deposits in Lek, Average Inflation rate is low but in lower level. The opposite happened with REPO because both grow together.

\section{Analysis of the IS curve}

\subsection{Who moves the IS curve?}

IS curve is closely related to the aggregate demand curve. At its foundation are the elements of this request.

The function of the aggregate demand curve is $A D=a+c(1-t) Y-b i$, while:

IS curve function (Investment - Savings) is $\mathrm{Y}=\mathrm{ag}(\hat{\mathrm{A}} \mathrm{BI})$ where: $=\mathrm{ag}(\hat{\mathrm{A}}-\mathrm{bi})$ where: ${ }^{M=\frac{1}{1-c(1-t)}}$

The difference between them is that in the case of the IS market have on balance therefore we suppose that $A D=$ $Y$. In this way the factors that are associated with $A D(C+I+G+T R)$ are also associated with IS.

In 2015 AD's elements are generally decreased. "While growing (according to the Bank of Albania) economic activity remains below its potential level. Aggregate demand is not sufficient to generate full utilization of production capacity, which is reflected in the still low inflation levels. "1

IS moves by elements associated with aggregate demand $(\hat{C}+\bar{I}+\breve{G}+\check{T} \check{R})$. Analysis of the elements shows:

$=\hat{C}$ (autonomous spending for final goods). When the move increasing expenses and the IS curve right down costs moves IS curve left. Albania does not have their growth, according to the Bank of Albania. "Private consumption shrank during the first six months of the year - mainly in response to uncertainty - and a slow recovery in the third quarter, shrank by $0.8 \%$ in year base for the first nine months of $2015^{\prime \prime}{ }^{2}$

$=\bar{I}$ (autonomous investment costs). When costs rise autonomous moves IS curve to the right and down move when it left. In Albania (according to the Bank of Albania) do not have their growth. "Unlike last year, the construction sector has given positive high contribut, estimated at $1.24 \%$. This sector has benefited from investment growth in $2015^{\prime \prime}$ 
= Ğ (government spending on purchases). When government purchases increase spending on IS curve moves to the right and when they sit moves IS in left. Albania does not have their growth (according to the Bank of Albania). "The budget expenditures at the end of 2015 were approximately 430.6 billion, with a contraction of $1.9 \%$ in annual terms." 4

$=\check{T} \mathrm{R}$ (spending on transfers of payments). When TR expenditure increases, the IS curve moves to the right, and when they sit IS curve moves to the left. Albania does not have increased these costs.

$=\mathrm{t}$ (taxes). In cases where increased taxes ( $\mathrm{t}$ ) IS going left and becomes steeper for lower multiplier (multiplier autonomous expenditure). In Albania (according to the Bank of Albania) "income from VAT, despite the high weight in total revenues (33\%) had a modest contribution to their growth this year $(0.5$ p.p). The performance of revenues from VAT, in the absence of legislative changes, reflecting the decrease in imports from a year ago (1.4\%), consumption weak this year, as well as lower prices of food stuffs and oil in world markets. Legal changes in 2015 related mostly personal income tax, national taxes and excise taxes are factored in slower growth of total revenues "5

$=$ In case the IS curve taxes goes right down and become flat because multiplier increases.

$\hat{A}$ elements $=\hat{C}+\bar{I}+\breve{G}+c \breve{T} \breve{R}$ determining displacement curve IS are reduced by moving the IS curve left. Increased taxes affecting moving IS curve left. In this way all these elements adversely affecting economic growth. In the Annual Report of the Bank of Albania for 2015 states: "Gross domestic product grew by $2.7 \%$ in the first nine months of the year, supported by rising investment and improving the balance of foreign trade exchanges. Economic growth marked an improvement for the second consecutive year, but economic activity still remains below its potential ${ }^{6}$ "and further" The economy has benefited from improved financing conditions, the balance on liquid businesses as a result of payment arrears in the public sector, the inflows of foreign direct investment, and the improvement of business and consumer confidence. On the other hand, economic growth continues to be restrained by high uncertainty and unfavorable foreign environment ".?

The general conclusion is that the components of aggregate demand, excluding investments and increased taxes have negatively impacted the growth of GDP.

\subsection{Who determines the slope of the IS curve?}

The function of the investment curve $(\mathrm{I})$ is $I=\bar{I}$-bi. Investment curve slope (I) defined by $b$ (coefficient of sensitivity of the investments related to the interest rate). The slope of the IS curve is determined by two factors: the multiplier and the coefficient $b$ ag. IS expresses slope coefficient of $-1 / a g$ * $b$.

If $c=$ MPC (marginal propensity to consumption) increases then the multiplier will increase. In this way we get a more flat curve IS. If you will take a lower multiplier IS curve more steep. In the case of the Albanian economy has been reduced as a result of lower multiplier of $C$.

$=$ When growing $b$ (coefficient of sensitivity to interest rate investments) IS curve becomes flatter and lower $b$ when IS curve becomes steeper. In the present case (see corresponding tables) B is reduced. This has resulted in IS curve becomes steeper.

= Since the tax is an important element of the tax multiplier change has a double impact, which has moved the IS curve and slope that has changed. Thus:

- When you increase taxes, IS goes left and becomes steeper for lower multiplier.

- When lower taxes, IS going right and become flat because multiplier increases.

Albanian economy have in the first case. We have increased taxation. In this way the IS curve becomes steeper and moves left.

The conclusion is simple. Almost all the factors have contributed to the slope of the IS curve making it almost completely vertical.

For the past 5 years the relationship between the repo rate and credit in Lek has been:

\footnotetext{
${ }^{4}$ Bank of Albania, Annual Raport 2015, pg 30

${ }^{5}$ Bank of Albania, Annual Raport 2015, pg 31. "Revenues from VAT on imports have negatively impacted the total VAT collected by the end of 11 months of the year. Dividends, income from profit partner, interest from loans deposits, copyright income, gambling, as well as income from bonuses was $15 \%$ (from $10 \%$ a). Turnover tax on petrol and diesel was 27 lek / liter (17 lek / liter was). Excise tax revenues shrank by $4.6 \%$ from a year ago, due to lower imports of fuels and tobacco, falling which failed to compensate the increase in excise duties on tobacco and its derivatives ".

${ }^{6}$ Bank of Albania, Annual Raport 2015, pg 6

${ }^{7}$ Bank of Albania, Annual Raport 2015, pg 14
} 
in million ALL

\begin{tabular}{|c|c|c|}
\hline Years & Loan & Interes Rate \\
\hline & $y$ & $x$ \\
\hline 2012 & $554,700.00$ & 4 \\
\hline 2013 & $547,900.00$ & 3 \\
\hline 2014 & $560,000.00$ & 2.25 \\
\hline 2015 & $546,500.00$ & 1.75 \\
\hline
\end{tabular}

\begin{tabular}{|c|c|} 
Correcation between them \\
\begin{tabular}{|c|c|}
\hline \multicolumn{2}{|c|}{ Regression Statistics } \\
\hline Multiple R & 0.2089842 \\
\hline R Square & 0.0436744 \\
\hline Adjusted R Square & -0.4344884 \\
\hline Standard Error & 7513.0502 \\
\hline
\end{tabular}
\end{tabular}

$F=0.091338$

ALL credit dynamics associated with BIR for 4 years has been:

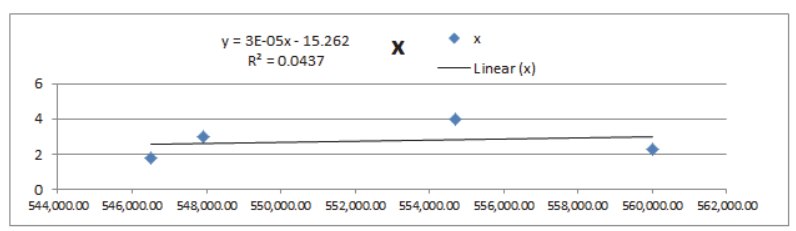

Chart no. 2. All loans interaction with BIR for 2012-2015

Position of ALL credit curve is sloping from the left and not the right. This means that the interest rate cut has also reduced the amount of the loan. The strength of this link is very small, which means that it tends to be completely vertical.

In the following analysis we take 19 months, to prove this trend, which appears in these last four years.

In this analysis position in domestic credit curve it is almost completely vertical. This means that it is insensitive to changes in interest rates.

The following curve (theoretical) have built based precisely on this curve.

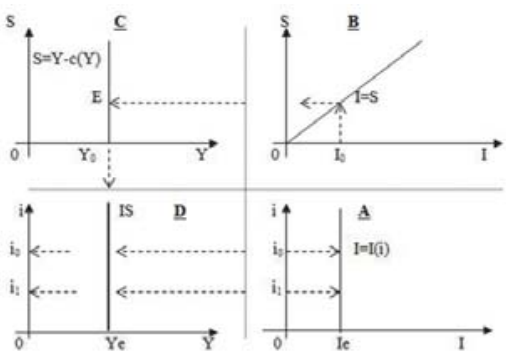

Chart No. 3. The result of the curve IS modeled Hicks-Hansen

A quadrant have built an investment market. Investment curve we get vertical starting from the data of the Albanian economy for the last 4 years. In this way of regarding both benefit balance almost completely vertical IS curve. This means that it is insensitive to interest rates. Being insensitive to interest rates is also insensitive to GDP.

Conclusion: GDP is insensitive to changes in base interest rates. 


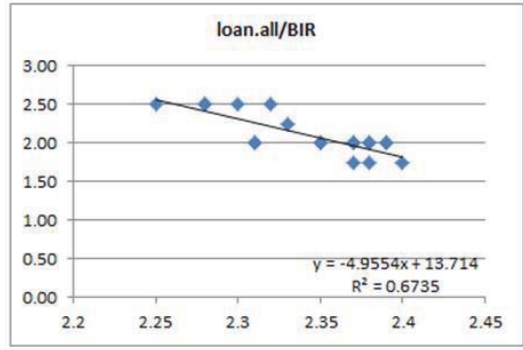

Chart No.4. Connection Dynamics BIR / credit in Lek (Using the data of Table 1)

Pearson coefficient of correlation coefficient and a negative result and the strong -0.82599 . This means that the slope of the curve is great, and if we consider the opposite screen. It is this reason that we take vertical IS curve. Even if no such take then have to consider not completely vertical with a very low impact on economic growth.

Conclusion. In case fiscal policy has no effect if the government will change the components of aggregate demand by applying an expansionist policy and not a styptic policy. This conclusion will deepen through the analysis that would make LM curve in terms of economy.

\section{Analysis of the LM Curve}

LM curve has a positive slope. This means that an increase in the interest rate reduces the demand for real balances. To keep the demand for real balances equal to the fixed supply should increase the level of income. As a result of the monetary market equilibrium implies that an increase in the interest rate associated with, an increase in the level of income. This theoretical connection under normal conditions, have shown in the figure below.

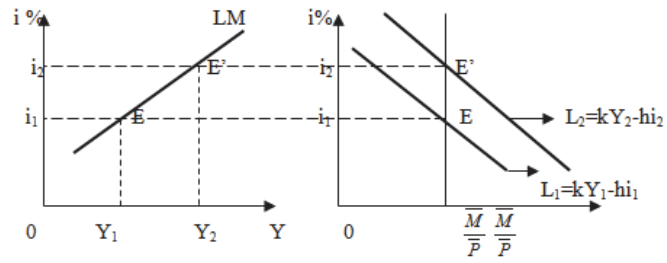

Chart No. 5. LM curve Derivation of a simple model of kejns equilibrium

Line find a combination of in $E$ between $Y_{1}$ level, income and interest rate $I_{1}$ for which we have equilibrium in the money market. If $L \uparrow \uparrow \rightarrow Y$, so will demand for money have redundancy. In this way we disequilibrium. To turn the balance should grow $\mathrm{i}_{1}$ to $\mathrm{i}_{2}$.

In point of $i_{2} E_{2}$ have combinations with $Y_{2}$. In this position we have equilibrium in the money market. By joining these two points $E$, E' trickle LM curve which represents all possible combinations between the $i$ and $Y$ for which we have equilibrium in the money market.

The ecuation of the curb is: ${ }^{i=\frac{1}{h}\left(k y-\frac{\bar{M}}{\bar{P}}\right)}$. In this way the LM curve or money curve market equilibrium shows all combinations of interest rates and income levels, such that the demand for real balances is equal to the offer of real balances. LM curve along the monetary market is in equilibrium. Refering the LM curve ask these questions:

a) What causes the LM curve moves? LM curve moves the money supply.

Increasing the money supply LM curve moves to the right, and a decrease in the money supply moves the LM curve to the left.

Case I $\uparrow \frac{\bar{M}}{\bar{P}} \Rightarrow L M \Rightarrow$ right 
Case $\| \stackrel{\downarrow}{\frac{\bar{M}}{\bar{P}}} \Rightarrow L M \Rightarrow$ left

b) Who determines the slope of the LM curve?

LM curve slope defines $\mathrm{H}$ (coefficient of sensitivity of money demand to changes in the aggregate revenues).

The function of the LM curve is:

$i=\frac{1}{h}\left(k y-\frac{\bar{M}}{\bar{P}}\right)$

If $\mathrm{h}=\rightarrow \infty$ will take a horizontal LM curve. Kejns case.

$=$ If $\mathrm{h}=0$ will take a vertical LM curve. The classic case.

$=$ The flat becomes more LM approaching change of mass displacement $\mathrm{Y}=\mathrm{IS}$.

$\mathrm{i} \%$

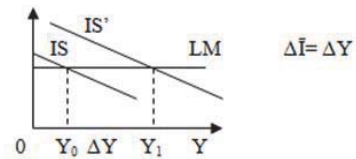

Chart no. 6. IS-LM model, the LM is completely flexible.

The flat LM curb more fiscal policy effect. Monetary policies have no effect.

= How much less steep LM approaching change of mass displacement $Y=I S$.

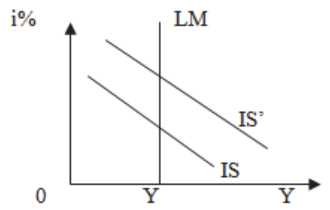

Chart no. 7. IS-LM model, the LM completely inelastic.

When we increase the demand for money, with a fixed monetary offer that claims to be equal to this offer should interest rates rise i. In this case affect monetary policy and fiscal policy are very few.

$\uparrow \bar{I} \rightarrow \uparrow l \rightarrow \uparrow A D \rightarrow \uparrow Y$ of $Y$ because $L=k Y-h i$

$\uparrow L \rightarrow \uparrow i \rightarrow \downarrow$ because I $=\bar{I}$ - bi so $\rightarrow \downarrow A D \rightarrow \downarrow Y$

$=$ How is precisely the situation in the Albanian economy, according to data for the last 20 months?

LM curve dot can derive from Hicks-Hansen variant have no motive for holding money speculation. So we derive from model Donbursh - Fisher. We will take money out of the bank as a monetary claim and monetary aggregate $\mathrm{M}_{2}$ offering for analyzing market appreciation rather than the market in general. This action made in determining the IS. In this case as I (investment) got all loans.

For the period 2004-2015, M2 aggregate curve in connection with BIR-in has been in this position:

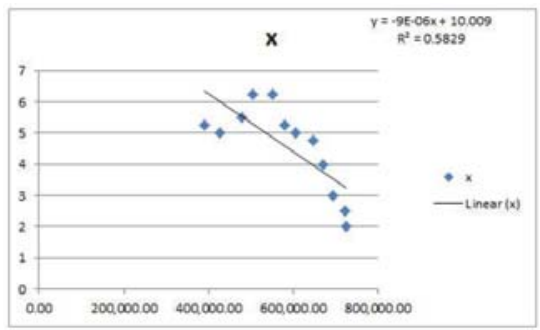

Chart no. 8. $\mathrm{M}_{2}$ about REPO from 2004 to 2015 
Below build chart for the last 19 months for $\mathrm{M}_{2}$. $\mathrm{M}_{2}$ will consider in domestic aggregate supply and PJB (currency outside banks as a requirement). The data for these charts we take from Table 1.

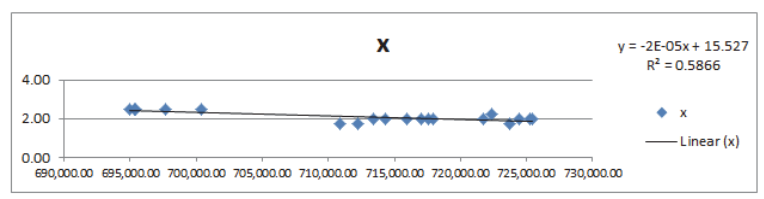

Chart No.9. $\mathrm{M}_{2}$ about BIR

Below you will find the elasticity coefficients between BIR and the $\mathrm{M}_{2}$ are divided into two areas, close to X's, Y-s close and in total.

\begin{tabular}{|c|c|c|c|c|c|c|c|}
\hline & & & & $d q-d r$ & $d q / d r$ & $r_{1} / \mathrm{Q}_{1}$ & $\varepsilon$ \\
\hline $\mathrm{Q}_{1}(1)$ & $697,654.00$ & $\mathrm{r} 1$ & 2.5 & $24,702.70$ & -98810.8 & $3.583 \mathrm{E}-06$ & -0.354 \\
\hline $\mathrm{Q}_{2}(6)$ & $722,356.70$ & $\mathrm{r} 2$ & 2.3 & -0.25 & & & \\
\hline & & & & $\mathrm{dq}-\mathrm{dr}$ & $\mathrm{dq} / \mathrm{dr}$ & $\mathrm{r} 1 / \mathrm{Q} 1$ & $\varepsilon$ \\
\hline $\mathrm{Q}_{1}(16)$ & $713,395.00$ & $\mathrm{r} 1$ & 2 & $-1,113.40$ & 4453.6 & $2.803 \mathrm{E}-06$ & -0.012 \\
\hline $\mathrm{Q}_{2}(19)$ & $712,281.60$ & $\mathrm{r} 2$ & 1.8 & -0.25 & & & \\
\hline
\end{tabular}

\begin{tabular}{|c|c|c|c|c|c|c|c|}
\hline & & & & $\mathrm{dq}-\mathrm{dr}$ & $\mathrm{dq} / \mathrm{dr}$ & $\mathrm{r} 1 / \mathrm{Q} 1$ & $\varepsilon$ \\
\hline $\mathrm{Q}_{1}(1)$ & $697,654.00$ & $\mathrm{r} 1$ & 2.5 & $14,627.60$ & -19503.467 & $3.583 \mathrm{E}-06$ & -0.0699 \\
\hline $\mathrm{Q}_{2}(19)$ & $712,281.60$ & $\mathrm{r} 2$ & 1.8 & -0.75 & & & \\
\hline & & & & $\mathrm{dq}-\mathrm{dr}$ & $\mathrm{dq} / \mathrm{dr}$ & $\mathrm{r} 1 / \mathrm{Q} 1$ & $\mathbf{e}$ \\
\hline
\end{tabular}

The data show that the aggregate supply curve is inelastic, in total, $1 \%$ of the BIR's decline brings $-0.0699 \%$ decrease. In part, this coefficient is 0.012 horizontal. In the near vertical $y$-mails is -0354 . The correlation coefficient is -0.7659 .

\begin{tabular}{|l|c|}
\hline \multicolumn{2}{|l|}{ Regression Statistics } \\
\hline Multiple R & 0.7659021 \\
\hline R Square & 0.5866061 \\
\hline Adjusted R Square & 0.5622888 \\
\hline Standard Error & 7204.5476 \\
\hline Observations & 19 \\
\hline$F=24.123$ & \multicolumn{1}{|l}{} \\
\cline { 1 - 2 } &
\end{tabular}

Conclusion curve is inelastic. The money outside banks. Chart for 19 months as follows:

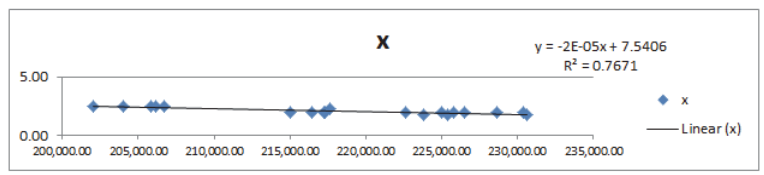

Chart No.10. The money outside banks about BIR.

Elasticity coefficients are as follows:

\begin{tabular}{|c|c|c|c|c|c|c|c|}
\hline $\mathrm{Q}_{1}(16)$ & $225,028.50$ & $\mathrm{r} 1$ & 2 & 394.60 & -1578.4 & $8.888 \mathrm{E}-06$ & $-\mathbf{0 . 0 1 4 0}$ \\
\hline $\mathrm{Q}_{2}(19)$ & $225,423.10$ & $\mathrm{r} 2$ & 1.75 & -0.25 & & & \\
\hline & & & & $\mathrm{dq}-\mathrm{dr}$ & $\mathrm{dq} / \mathrm{dr}$ & $\mathrm{r} 1 / \mathrm{Q} 1$ & $\mathrm{e}$ \\
\hline $\mathrm{Q}_{1}(1)$ & $202,024.40$ & $\mathrm{r} 1$ & 2.5 & $15,641.20$ & -62564.8 & $1.237 \mathrm{E}-05$ & $-\mathbf{- 0 . 7 7 4 2}$ \\
\hline $\mathrm{Q}_{2}(6)$ & $217,665.60$ & $\mathrm{r} 2$ & 2.25 & -0.25 & & & \\
\hline $\mathrm{Q}_{1}(1)$ & $202,024.40$ & $\mathrm{r} 1$ & 2.5 & $23,398.70$ & -31198.267 & $1.23747 \mathrm{E}-05$ & $-\mathbf{0 . 3 8 6 1}$ \\
\hline $\mathrm{Q}_{2}(19)$ & $225,423.10$ & $\mathrm{r} 2$ & 1.75 & -0.75 & & & \\
\hline
\end{tabular}


The signs indicate that the curve is not elastic and inelastic base near the Y's. An average of $1 \%$ of the BIR's cuts have $0.3861 \%$ of the money outside banks 's growth. The curve is almost parallel with the curve $\mathrm{M}_{2}$. Their slope is $30806 / 31161$.

\begin{tabular}{|l|c|}
\hline Regression Statistics \\
\hline Multiple R & 0.87586 \\
\hline R Square & 0.76713 \\
\hline Adjusted R Square & 0.753432 \\
\hline Standard Error & 4674.6 \\
\hline Observations & 19 \\
\hline F=56 &
\end{tabular}

These data indicate that the curves are almost parallel and inelastic. Because MOB has lower slope means that the screen is. Generally we have this position:

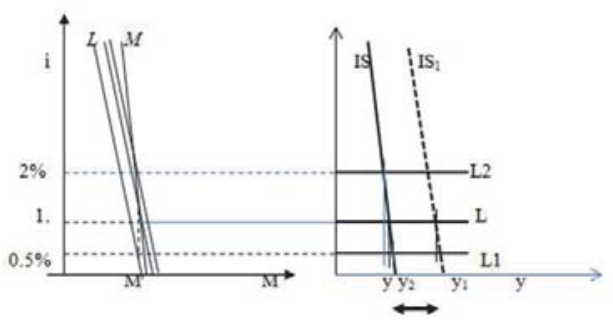

Chart No.11. Case Albanian economy IS-LM model

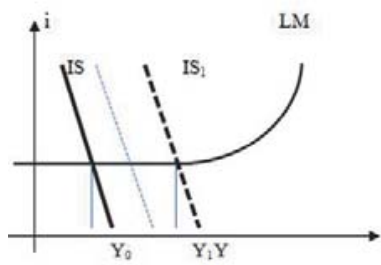

Chart No.12. Kejns case of the liquidity trap is:

In this case it affects fiscal policy, not monetary policy.

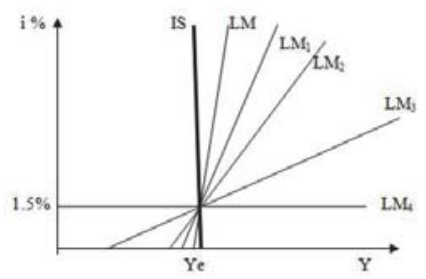

Chart No.13. The position of the curves in the Albanian economy. LM is flexible while IS is fixed..

Even the LM curve is inelastic, the LM position. If we pass on fully flexible curve then, even in this case its growing impact on economic growth would be quite insensitive. So in this case only will move the IS right trigger economic growth.

Reduce $L(M O B)$ leads decrease left of $M$. This leads by its diminution $Y$. Its growth leads to increased $M$ but in a very small extent. 0 to $\mathrm{M}$ that affects spindle. Even in this case will not have any impact on the growth of $\mathrm{M}$, result in 
increased Y. Even if you move the right it will avoid bringing the initial balance increase (i) and decreases M. If lower then the maximum zero equals $M$ that affects axis $X$ 's.

These yield curve impact on the curve L. It plays along the IS curve which is almost vertical. LM so moving up and down does not have any impact on the growth of $Y$. Maximum is that it will affect the rate of $0 \%$ in IS intersection with the $X$-axis $Y_{2}$ widow. In these conditions, which affect fiscal policy with an increase in $G$ will move IS in IS 1 . This move will mean increasing the $Y$ to $Y_{1}$. In this way it will boost economic growth.

\section{Conclusions and Recommendations}

- Our economy is in a liquidity trap, despite the LM curve is not completely inelastic. While the IS curve is completely inelastic which invalidates monetary policy regardless of the position of the LM curve.

- In this situation the only economic growth fiscal policy effects. In this situation affects the weight of foreign currencies (Euro/USD) on the market, versus 40 percent of Albanian Lek. Foreign currency accounts for around $60 \%$ of loans and almost $50 \%$ of the deposit, which has its effects on the economic situation. BoA suggest to study the possibility to avoid as much on foreign currency deposits and loans because they have a negative impact on the effect of, transmission of monetary policy.

- The main factor to economic growth were exports and foreign investment.

- For this reason we recommend money emission by Bank of Albania on behalf of the budget, which the government pays part of the debt to the banks of the second level and a use for salaries and pensions by stimulating the growth of consumption (C).

- This will boost aggregate expenditures (AD) and aggregate supply consequence (AS). This will activate the economy, without being accompanied by inflation because the market there is a significant lack of money.

\section{References}

Makroekonomiks. Prof.Dr.Akademik A.Angjeli, Prof. A.Kadriu, Prof.As.Dr. A.Naqellari 2011. Struga, Macedonia.

Source: http://cuadernoskeynesianos.blogspot.al/2008/10/vuelve-la-trampa-de-la-liquidez.html

Bank of Albania. Annual Report 2015.

Bank of Albania. Statistical Report, february 2016.

Bank of Albania. Statistical Report, 2015, 2014, 2013, 2012, 2011, 2010, 2009, 2008, 2007, 2006.

El Modelo IS-LM. Prof. Antonio Santillana del Barrio y Ainhoa Herrarte Sánchez Universidad Autónoma de Madrid Curso $2012-2013$.

N.Gregori Mankiŵ. Macroeconomics, Fourth Edition, USA 2000.

Abel /Bernanke. Macroeconomics, Third edition 1998 U.S.A.

Sloman.J. Economics. Fourth edition. England 2000.

Samuelson.P.etc. Economics. Thirteenth edition. USA 1989.

David C. Colander. Economics.USA 2001.

Rudinger Dornbuch \& Stanley Fischer. 1994. Botim ndërkombëtar. Tiranë 2000. Makroekonomia.

P. Krugman (1999): Thinking About The Liquidity Trap.

Krugman, Paul (2010). "Hoŵ much of the ŵorld is in a liquidity trap?"; The Neŵ York Times, 17 March 2010.

Krugman, Paul (2012).Acabad ya con esta crisis!. Barcelona: Planeta. ISBN 978-84-9892-405-3 cuadernoskeynesianos .La deflación y la trampa de la liquidez.

http://ŵŵî.economia48.com/spa/d/trampa-de-la-liquidez/trampa-de-la-liquidez.htm

http://ŵeb.archive.org/ŵeb/20130311140217/http://ŵŵw.neŵyorkfed.org/research/economists/eggertsson/palgrave.pdf 
